Southern Illinois University Carbondale

OpenSIUC

Publications

Fisheries and Illinois Aquaculture Center

$8-2006$

\title{
Riparian Shading and Groundwater Enhance Growth Potential for Smallmouth Bass in Ozark Streams
}

\author{
Gregory W. Whitledge \\ Southern Illinois University Carbondale \\ Charles F. Rabeni \\ U.S. Geological Survey \\ Gust Annis \\ University of Missouri \\ Scott P. Sowa \\ University of Missouri
}

Follow this and additional works at: http://opensiuc.lib.siu.edu/fiaq pubs

(C) 2004 by the Ecological Society of America

Published in Ecological Applications, Vol. 16, No. 4 (August 2006) at doi: 10.1890/

1051-0761(2006)016[1461:RSAGEG]2.0.CO;2

\section{Recommended Citation}

Whitledge, Gregory W., Rabeni, Charles F., Annis, Gust and Sowa, Scott P. "Riparian Shading and Groundwater Enhance Growth Potential for Smallmouth Bass in Ozark Streams." (Aug 2006).

This Article is brought to you for free and open access by the Fisheries and Illinois Aquaculture Center at OpenSIUC. It has been accepted for inclusion in Publications by an authorized administrator of OpenSIUC. For more information, please contact opensiuc@lib.siu.edu. 


\title{
RIPARIAN SHADING AND GROUNDWATER ENHANCE GROWTH POTENTIAL FOR SMALLMOUTH BASS IN OZARK STREAMS
}

\author{
Gregory W. Whitledge,,${ }^{1,4}$ Charles F. Rabeni, ${ }^{2}$ Gust Annis, ${ }^{3}$ and Scott P. Sowa ${ }^{3}$ \\ ${ }^{1}$ Department of Fisheries and Wildlife Sciences, 302 Anheuser-Busch Natural Resources Building, University of Missouri, \\ Columbia, Missouri 65211-7240 USA \\ ${ }^{2}$ U.S. Geological Survey, Biological Resources Division, Missouri Cooperative Fish and Wildlife Research Unit \\ 302 Anheuser-Busch Natural Resources Building, University of Missouri, Columbia, Missouri 65211-7240 USA \\ ${ }^{3}$ Missouri Resource Assessment Partnership, University of Missouri, 4200 New Haven Road, Columbia, Missouri 65201 USA
}

\begin{abstract}
Moderation of stream temperatures by riparian shading and groundwater are known to promote growth and survival of salmonid fishes, but effects of riparian shade and groundwater on to be growth of warmwater stream fishes are poorly understood or assumed to be negligible. We used stream temperature models to relate shading from riparian vegetation and groundwater inflow to summer water temperatures in Missouri Ozark streams and evaluated effects of summer water temperatures on smallmouth bass, Micropterus dolomieu, growth using a bioenergetics model. Bioenergetics model simulations revealed that adult smallmouth bass in non-spring-fed streams have lower growth potential during summer than fish in spring-fed streams, are subject to mass loss when stream temperatures exceed $27^{\circ} \mathrm{C}$, and will likely exhibit greater interannual variation in growth during summer if all growth-influencing factors, other than temperature, are identical between the two stream types. Temperature models indicated that increased riparian shading will expand the longitudinal extent of thermal habitat capable of supporting adult smallmouth bass growth in spring-fed stream reaches when mean daily air temperatures exceed $27^{\circ} \mathrm{C}$. Optimum growth temperature $\left(22^{\circ} \mathrm{C}\right)$ will be present only in spring-fed streams under these conditions. Potential for increasing shade through riparian restoration is greatest for streams $<5 \mathrm{~m}$ wide and along north-south reaches of larger streams. However, temperature models also indicated that restoring riparian shading to maximum levels throughout a watershed would increase the total stream mileage capable of supporting positive growth of adult smallmouth bass by only 1-6\% when air temperatures are at or near average summer maxima; increases in suitable thermal habitat would be greatest in watersheds with higher spring densities. Riparian management for maintenance or restoration of the thermal habitat of adult smallmouth bass during summer should be focused in areas strongly influenced by groundwater. Restoring riparian shading along spring-fed warmwater streams will likely benefit adult smallmouth bass growth and may ultimately influence population sizes.
\end{abstract}

Key words: bioenergetics; climate change; growth; Micropterus dolomieu; Missouri; Ozarks; riparian vegetation; springs; streams; temperature.

\section{INTRODUCTION}

Water temperature exerts a substantial influence on stream ecosystem structure and function (Allan 1995). Temperature regulates activity, metabolic processes, growth and development of organisms, acts as a lethal agent, controls geographic distributions of species, influences responses to other environmental factors, and serves as a cue for timing of key life events, such as reproduction or migration (Fry 1971, Coutant 1976). Recognition of the ecological significance of water temperature has made preventing or mitigating anthro-

Manuscript received 3 November 2005; accepted 8 December 2005. Corresponding Editor: T. Essington.

4 Present address: Fisheries and Illinois Aquaculture Center, Department of Zoology, Southern Illinois University, Carbondale, Illinois 62901-6511 USA.

Email: gwhit@siu.edu pogenic thermal degradation in streams a common concern among resource managers (Coutant 1999).

Stream temperatures are driven by meteorological, hydrological, and geomorphological factors (Poole and Berman 2001). Often, groundwater temperature serves as the baseline temperature in headwater streams, with stream temperatures diverging from groundwater temperature and converging with air temperature with increasing distance downstream (Sullivan and Adams 1989, Poole and Berman 2001). Longitudinal trends in stream temperature can be interrupted by inputs of lateral surface water or groundwater (Holmes 2000, Poole and Berman 2001). Shading by riparian vegetation acts to reduce the longitudinal rate of stream warming and curtails daily water temperature fluctuation, particularly in headwater streams (Sullivan and Adams 1989, Rutherford et al. 2004). Removal of riparian vegetation typically increases mean and maximum water temperatures when air temperatures exceed groundwater 
temperature (Brown and Krygier 1970, Burton and Likens 1973, Hewlett and Fortson 1982, Barton et al. 1985, Beschta and Taylor 1988, Power et al. 1999).

Altered thermal regimes following loss of riparian vegetation can result in changes in fish and benthic invertebrate community structure (Newbold et al. 1980, Barton et al. 1985, Sweeney 1995, Rabeni et al. 1997). However, only a few studies have recommended riparian buffer strip dimensions for maintaining or restoring suitable thermal habitat for particular lotic species or assemblages (e.g., Barton et al. 1985). Many factors influence the effectiveness of riparian buffer strips, including climate, terrain, type of vegetation, and soil type, and thus it is likely that there will be some geographic variation in required dimensions for effective riparian buffer strips (Barton et al. 1985). Published studies that have investigated the role of riparian vegetation in maintaining or restoring suitable water temperatures for aquatic organisms have been conducted in streams that support or formerly supported salmonids (e.g., Barton et al. 1985, Theurer et al. 1985, Hetrick et al. 1998, Blann et al. 2002). No information is currently available concerning quantities of riparian shading required to maintain or restore suitable thermal regimes for warmwater stream fauna, perhaps because warmwater fishes have relatively high critical thermal maxima (Matthews 1987, Smale and Rabeni 1995) and are generally believed to be more eurythermal than their coldwater counterparts.

Endemic smallmouth bass, Micropterus dolomieu, have declined in abundance during the last 50 years in the northern Ozarks and Ozark border regions of Missouri (Bauman 1945, Pflieger 1975, Fajen 1981) and have been replaced by largemouth bass $M$. salmoides and introduced spotted bass $M$. punctulatus in some streams (Fajen 1981, Sowa and Rabeni 1995). Densities of smallmouth bass were negatively associated with maximum summer water temperatures and percentage of pool area in Ozark border streams, whereas largemouth bass densities were positively related to each of these variables (Sowa and Rabeni 1995). Alteration of riparian vegetation has been implicated as a likely cause of thermal and physical habitat degradations that tend to favor largemouth bass over smallmouth bass (Sowa and Rabeni 1995). Interspecific differences in optimum temperatures for growth and scope for growth at temperatures $>22^{\circ} \mathrm{C}$ may be partly responsible for the displacement of smallmouth bass by largemouth bass in northern Ozark and Ozark border streams that have been negatively affected by land use practices (Zweifel et al. 1999, Whitledge et al. 2002).

The objectives of this research were to quantify the effects of riparian shading and groundwater inflow on summer water temperatures in warmwater streams in Missouri's northern Ozark and Ozark border regions and to link relations between riparian shading, groundwater inflow, and summer water temperatures to thermal habitat and growth of smallmouth bass. We used the Stream Segment Temperature and Stream Network Temperature Models (SSTEMP and SNTEMP, Bartholow 1989) to quantify influences of riparian shading on stream temperatures during summer at segment and watershed scales, determined the maximum amount of riparian shading that can reasonably be expected during summer for northern Ozark and Ozark border streams, and collected additional empirical data relating riparian shading and spring flow to daily mean water temperature and daily temperature fluctuation in headwater streams of this region. A bioenergetics model (Whitledge et al. 2003) was used to evaluate effects of different stream temperature regimes during summer on smallmouth bass growth.

\section{Methods}

\section{Study area}

The Ozark border region of Missouri is a transitional zone separating the glaciated and unglaciated prairie physiographic regions to the north and the Ozark Plateaus to the south (Collier 1955, Thom and Wilson 1980, Sowa and Rabeni 1995). Mean annual air temperature is $13^{\circ} \mathrm{C}$ and mean annual precipitation is $104 \mathrm{~cm}$, most of which falls as rain during spring, summer, and early fall (Climate Center, University of Missouri at Columbia; unpublished data). Geologically, the northern Ozark and Ozark border regions are characterized by cherty dolomite interspersed with sandstone and shale deposits (Thom and Wilson 1980). Karst topography accounts for the large number of sinkholes, caves, and springs. Terrain ranges from gentle to moderately sloping hills with narrow ridgetops and valleys forming dendritic drainage systems (Collier 1955, Thom and Wilson 1980). Elevations in the Ozarks commonly exceed $300 \mathrm{~m}$ and the tops of hills often stand $90 \mathrm{~m}$ or more above the beds of nearby streams (Collier 1955). Presettlement vegetation was dominated by upland deciduous forest with lesser amounts of glade, prairie, and bottomland forest (Thom and Wilson 1980). Presently, uplands are characterized by second-growth oak-hickory forest with bottomland hardwoods along the larger rivers (MDC 1991). Land use consists of a mix of agriculture, meat and dairy production, woodland, and industry (Collier 1955, Smale and Rabeni 1991).

\section{Stream temperature models}

We used two related models (SSTEMP and SNTEMP, Bartholow 1989) to quantify influences of riparian shading and groundwater inflow on summer water temperatures in northern Ozark and Ozark border streams. SSTEMP was designed to predict mean, minimum, and maximum water temperatures for a stream segment with a given set of stream geometric, hydrologic, and shading characteristics over a specified time period. SNTEMP is an extension of SSTEMP that enables simultaneous water temperature predictions for multiple stream segments linked within a watershed. Both models calculate net heat flux for each stream 
segment as the sum of heat to or from atmospheric longwave radiation, direct short-wave solar radiation, convection, conduction, evaporation, topographic and riparian vegetation radiation and shading, streambed friction, and the water's back radiation (Bartholow 1989). The models are based on a dynamic temperaturesteady flow equation and assume that all input data, including meteorological and hydrological variables, can be represented by $24-\mathrm{h}$ averages. Each stream segment is described by its length, width, slope, channel roughness or water travel time, and riparian and topographic shading characteristics. Meteorological influences on water temperature are accounted for by measurements of air temperature, relative humidity, wind speed, percentage of possible sun, and ground-level solar radiation. Discharges of surface and ground water into each stream segment, along with their respective water temperatures, are also required inputs. SSTEMP and SNTEMP have been used to evaluate effects of stream channel and riparian vegetation removal and restoration on water temperatures in coldwater streams (Theurer et al. 1985, Bartholow 1991, 2000, Blann et al. 2002) and have been used in conjunction with fish population models to assess temperature effects on stream salmonids (Bartholow et al. 1993, Newcomb 1998). Water temperature predictions of the SSTEMP model have been tested during summer low-flow periods in both spring-fed and non-spring-fed northern Ozark and Ozark border streams with a wide range of riparian conditions and discharges ranging from 0.020 to 1.56 $\mathrm{m}^{3} / \mathrm{s}$ (Whitledge 2001). Predicted mean daily stream temperatures were never $>1{ }^{\circ} \mathrm{C}$ different from corresponding observed mean daily temperatures; mean errors for predicting daily mean and daily maximum and minimum stream temperatures were $0.36^{\circ} \mathrm{C}$ and $0.58^{\circ} \mathrm{C}$, respectively (Whitledge 2001).

Empirical data were collected to complement simulation models in assessing effects of riparian shading on daily mean water temperature and daily temperature fluctuation in spring-fed and non-spring-fed headwater streams in our study area. These data were used to confirm the correspondence between mean daily air and water temperatures for non-spring-fed headwater streams and provided additional data to test SSTEMP's minimum and maximum water temperature predictions. Temperature loggers (Optic StowAway Temp, Onset, Bourne, Massachusetts, USA) were placed in 18 streams with discharges of $0.028-0.042 \mathrm{~m}^{3} / \mathrm{s}$ (watershed areas of 13.7-35.4 km²) during 7-9 July 2000. This three-day period was characterized by stable, hot (mean daily air temperature $27.9^{\circ} \mathrm{C}$ ), humid (mean dew point temperature $23.3^{\circ} \mathrm{C}$ ), and sunny weather conditions in which riparian shade was expected to have a strong influence on water temperatures. Eight temperature loggers were placed in streams within $1 \mathrm{~km}$ downstream of known spring locations. Loggers were positioned at these distances because preliminary modeling using SSTEMP indicated that spring-fed streams with discharges of
$0.028 \mathrm{~m}^{3} / \mathrm{s}$ would likely warm to near equilibrium with mean daily air temperature at distances of $1.0-1.3 \mathrm{~km}$ from springs in the absence of additional groundwater inputs. Ten temperature loggers were placed in streams that were not spring-fed according to a GIS database developed by the Missouri Department of Natural Resources, USGS topographic maps, and personal observations. Both spring-fed and non-spring-fed streams were chosen to encompass a broad range of riparian conditions (unshaded to well-shaded by a mature riparian canopy). Loggers recorded water temperatures every $15 \mathrm{~min}$ and were placed in locations in which no major changes in riparian conditions were present for at least $1 \mathrm{~km}$ upstream. To determine the percentage of shade in 1-km stream segments upstream of logger locations, transects were established every 50 $\mathrm{m}$ and vegetation height, crown diameter, offset (distance from stream edge), and density were determined for both stream banks at each transect using procedures described in Bartholow (1989). Means for riparian vegetation parameters, as well as stream width, azimuth, and latitude were entered in the SSSHADE (stream segment shade model) component of the SSTEMP model to calculate percentage of shade for $1-\mathrm{km}$ reaches upstream of logger locations. Leastsquares linear regression was used to describe relations between percentage of shade and both daily mean water temperature and daily temperature fluctuation (difference between daily maximum and daily minimum water temperatures) for the combined set of spring-fed and non-spring-fed streams.

\section{Maximum possible shade and stream size}

The SSSHADE component of the SSTEMP model was used to determine the maximum possible percentage of shade from riparian vegetation that can reasonably be expected during summer for northern Ozark and Ozark border streams ranging from 3 to $20 \mathrm{~m}$ in width. Riparian vegetation parameters required by the SSSHADE program for calculating percentage of shade (vegetation height, crown diameter, offset, and density; Bartholow 1989) and stream widths were measured at 72 locations along twelve northern Ozark and Ozark border streams for which riparian vegetation was visually judged to be at or near its maximum shadeproducing capacity. Mean values for each shading parameter (Table 1) were entered into the SSSHADE program for both stream banks. Using the SSSHADE model allowed calculation of percentage of shade that would be produced by riparian vegetation with a given set of near-maximum shade-producing characteristics along hypothetical streams of varying width $(3-20 \mathrm{~m})$. All simulations were run under the condition that no topographic shade was present. Latitude was set to correspond with Columbia, Missouri $\left(38^{\circ} 56^{\prime} \mathrm{N}\right)$. Day of year was set at 24 July in SSSHADE to approximate the time of year in which maximum air and water temperatures typically occur. Simulations for predicting max- 
TABLE 1. Values for parameters used in the SSSHADE model to predict maximum possible shade as a function of stream width for northern Ozark and Ozark border streams.

\begin{tabular}{lcc}
\hline \hline \multicolumn{1}{c}{ Parameter } & Mean & 95\% confidence limits \\
\hline Tree height $(\mathrm{m})$ & 27.7 & $25.1,30.3$ \\
Crown diameter $(\mathrm{m})$ & 7.5 & $6.3,8.7$ \\
Vegetation offset $(\mathrm{m})$ & 7.95 & $6.22,9.68$ \\
Vegetation density (\%) & 85.0 & 77,93 \\
\hline
\end{tabular}

Notes: Values shown for each variable are means and 95\% confidence limits obtained from 72 locations on 12 streams. Only mean values were entered into the model.

imum possible percentage of shade as a function of stream width were run for hypothetical streams flowing north-south (azimuth $=0^{\circ}$ ) and east-west (azimuth $=$ $\left.90^{\circ}\right)$.

\section{Shade-water temperature relations for $1-\mathrm{km}$ reaches}

A series of simulations were conducted using SSTEMP to quantify the effect of riparian shading on water temperatures in hypothetical, representative 1-km reaches of northern Ozark and Ozark border streams during summer low-flow conditions. For all simulations, meteorological parameters required by SSTEMP (mean daily values for air temperature, relative humidity, wind speed, percentage of possible sun, solar radiation, and day length) were set to levels typical of the warmest weather that occurs in Columbia, Missouri during an average year, which usually occurs in late July (Table 2). This was done to insure that model predictions of quantities of shade required to prevent stream temperatures from exceeding some value would be adequate for achieving such a goal $100 \%$ of the time during an average year. Data describing the set of meteorological conditions typical of the warmest, sunny, humid, late July day that occurs in an average year were obtained from the National Climatic Data Center's climatologic data for Columbia Regional Airport (data for 19681997) and from the Climate Center at the University of Missouri at Columbia. Simulations relating riparian shading to water temperature under these meteorological conditions were performed for hypothetical 1-km stream reaches with four levels of stream discharge $\left(0.028,0.142,0.283\right.$, and $\left.1.42 \mathrm{~m}^{3} / \mathrm{s}\right)$. Each set value for discharge was used to characterize stream size during late July and was assigned corresponding values for stream width, slope, and travel time (Table 2) based on data from northern Ozark and Ozark border streams used to validate the SSTEMP model (Whitledge 2001). Inflow temperature (water temperature at the upstream end of the reach) was set at either mean annual air temperature (Power et al. 1999) to correspond with temperature of phreatic groundwater in the Ozarks $\left(13^{\circ} \mathrm{C}\right)$ or at $29^{\circ} \mathrm{C}$ to represent a stream at equilibrium with mean daily air temperature used in the simulations. For simulations involving hypothetical spring-fed streams (inflow temperature $13^{\circ} \mathrm{C}$ ), rates of groundwater seepage into stream reaches were set at levels ranging from $0.0048-0.0161 \mathrm{~m}^{3} \cdot \mathrm{km}^{-1} \cdot \mathrm{s}^{-1}$ depending on stream discharge (Table 2). Groundwater inflow rates were obtained from data for seepage runs from streams in the Little Piney Creek watershed, southwest of Rolla, Missouri, USA, a basin in which springs and groundwater seeps are relatively common and contribute strongly to surface flow (Tryon 1974). The output from the series of simulations described herein was a set of relations between riparian shading (ranging from no shade to the maximum level for a given stream size) and daily changes in mean, maximum, and minimum water temperatures for hypothetical $1-\mathrm{km}$ reaches of springfed and non-spring-fed streams of various discharges under the meteorological conditions specified in Table 2.

SSTEMP was also employed to determine longitudinal distances required for daily mean temperatures in northern Ozark and Ozark border streams originating from springs with discharges ranging from 0.028-1.42 $\mathrm{m}^{3} / \mathrm{s}$ to warm to $22^{\circ} \mathrm{C}$, the optimum temperature for growth of older juvenile and adult smallmouth bass (Whitledge et al. 2002), and to mean daily air temperature used in these simulations described above $\left(29.5^{\circ} \mathrm{C}\right)$. Values for meteorological, hydrological, and stream geometry parameters were identical to those used in simulations relating percentage of shade to water temperature in hypothetical $1-\mathrm{km}$ reaches of spring-fed streams (Table 2). Distances below springs at which mean daily water temperatures would reach $22^{\circ}$ and $29.5^{\circ} \mathrm{C}$ were calculated for unshaded streams and for maximally shaded north-south and east-west flowing

TABLE 2. Values for SSTEMP model parameters used during the warmest conditions experienced during an average year to develop relationships between riparian shading and stream temperature in hypothetical 1-km reaches of northern Ozark and Ozark border streams.

\begin{tabular}{|c|c|}
\hline Parameter & Value(s) \\
\hline Discharge $\left(\mathrm{m}^{3} / \mathrm{s}\right)$ & $0.028 ; 0.142 ; 0.283 ; 1.42$ \\
\hline Inflow temperature $\left({ }^{\circ} \mathrm{C}\right)$ & $13 ; 29$ \\
\hline Segment length $(\mathrm{km})$ & 1 \\
\hline Travel time $\dagger(\mathrm{s} / \mathrm{km})$ & $64870 ; 35521 ; 28369 ; 16005$ \\
\hline Elevation upstream (m) & 185.93 \\
\hline Elevation downstream $\uparrow(\mathrm{m})$ & $181.05 ; 181.97 ; 182.88 ; 183.79$ \\
\hline Stream width $\dagger(\mathrm{m})$ & $5 ; 7 ; 10 ; 14$ \\
\hline $\begin{array}{l}\text { Mean daily air } \\
\text { temperature }\left({ }^{\circ} \mathrm{C}\right)\end{array}$ & 29.4 \\
\hline Relative humidity $(\%)$ & 85 \\
\hline Wind speed $(\mathrm{km} / \mathrm{h})$ & 12.88 \\
\hline Possible sun (\%) & 90 \\
\hline Solar radiation $\left(\mathrm{J} \cdot \mathrm{m}^{-2} \cdot \mathrm{s}^{-1}\right)$ & 322.92 \\
\hline Day length (h) & 14.3 \\
\hline $\begin{array}{l}\text { Ground/lateral inflow } \\
\text { temperatures }\left({ }^{\circ} \mathrm{C}\right)\end{array}$ & 13 \\
\hline $\begin{array}{l}\text { Thermal gradient } \\
\left(\mathrm{J} \cdot \mathrm{m}^{-2} \cdot \mathrm{s}^{-1} \cdot{ }^{\circ} \mathrm{C}\right)\end{array}$ & 1.65 \\
\hline Maximum shadet, $\$(\%)$ & $68 ; 66 ; 62 ; 58$ \\
\hline $\begin{array}{l}\text { Groundwater inflow } \dagger \\
\left(\mathrm{m}^{3} \cdot \mathrm{s} \cdot \mathrm{km}^{-1}\right)\end{array}$ & $0.0048 ; 0.0057 ; 0.0071 ; 0.0161$ \\
\hline
\end{tabular}
Note: SSTEMP is Stream Segment Temperature Model.

$\dagger$ Varied in conjunction with discharge: $0.028,0.142,0.283$, and $1.42 \mathrm{~m}^{3} / \mathrm{s}$, respectively.

\$ Percentage shade is given as zero to the maximum level per stream discharge level. 
TABLE 3. Latitude and longitude, watershed area, total linear stream distance, and number of springs present for four watersheds in the Meramec River basin, Missouri, that were chosen for modeling effects of riparian shading on gains in smallmouth bass thermal habitat during summer at a watershed scale.

\begin{tabular}{|c|c|c|c|c|c|c|}
\hline \multirow[b]{2}{*}{ Watershed } & \multirow{2}{*}{$\begin{array}{l}\text { Latitude, } \\
\text { longitude at } \\
\text { downstream } \\
\text { terminus }\end{array}$} & \multirow{2}{*}{$\begin{array}{c}\text { Area } \\
\left(\mathrm{km}^{2}\right)\end{array}$} & \multirow{2}{*}{$\begin{array}{l}\text { Linear } \\
\text { stream } \\
\text { distance } \\
(\mathrm{km})\end{array}$} & \multirow{2}{*}{$\begin{array}{l}\text { No. } \\
\text { springs } \\
\text { present }\end{array}$} & \multicolumn{2}{|c|}{$\begin{array}{l}\text { Gain in } \leq 27^{\circ} \mathrm{C} \text { habitat } \\
\text { with full riparian shading } \dagger\end{array}$} \\
\hline & & & & & Length (km) & Increase $(\%)$ \\
\hline Dry Fork & $37.86^{\circ} \mathrm{N}, 91.66^{\circ} \mathrm{W}$ & 61 & 200.39 & 21 & 2.66 & 1.3 \\
\hline Upper Meramec & $37.88^{\circ} \mathrm{N}, 91.43^{\circ} \mathrm{W}$ & 54 & 142.16 & 52 & 7.23 & 5.1 \\
\hline Huzzah Creek & $37.97^{\circ} \mathrm{N}, 91.22^{\circ} \mathrm{W}$ & 66 & 197.69 & 56 & 11.31 & 5.7 \\
\hline Courtois Creek & $38.03^{\circ} \mathrm{N}, 91.21^{\circ} \mathrm{W}$ & 56 & 162.70 & 28 & 6.83 & 4.2 \\
\hline
\end{tabular}

$\dagger$ Predicted absolute $(\mathrm{km})$ and relative (\% increase) gains in total linear extent of streams with mean daily water temperatures capable of supporting positive growth of adult smallmouth bass $\left(\leq 27^{\circ} \mathrm{C}\right)$ in response to increasing riparian shade from zero to maximum levels, given stream size and azimuth.

streams. Maximum percentage of shade values varied with stream size (discharge) and are shown in Table 2.

\section{Evaluating effects of summer temperature regimes on smallmouth bass growth}

A bioenergetics model (Whitledge et al. 2003) was used to assess how various stream temperature regimes during the period of 1 June-31 August might affect growth of older juvenile and adult smallmouth bass. Stream temperature regimes included a constant temperature of $22^{\circ} \mathrm{C}$, simulating potential growth in a springfed stream in which fish could continuously occupy areas with optimum growth temperature, and three temperature regimes designed to mimic day-to-day changes in mean water temperature characteristic of small $(<1.42$ $\mathrm{m}^{3} / \mathrm{s}$ ), non-spring-fed northern Ozark and Ozark border streams during summer. The three temperature regimes for streams lacking groundwater inflow were simulated mean daily water temperatures derived from historical June-August daily air temperature data from Columbia Regional Airport for years in which mean June-August air temperatures were $0.1^{\circ} \mathrm{C}$ below $(1996), \sim 1^{\circ} \mathrm{C}$ above (1999), and $\sim 6^{\circ} \mathrm{C}$ above (1980) the prior 30-year averages (National Climate Data Center, available online). ${ }^{5}$ The 1980 thermal regime was included to represent conditions in an extremely warm summer or in the context of long-term climate change; mean JuneAugust air temperatures were predicted to increase by $\sim 6^{\circ} \mathrm{C}$ in Missouri under a doubling of atmospheric $\mathrm{CO}_{2}$ (Eaton and Scheller 1996). Daily water temperatures for non-spring-fed streams in modeling simulations were set at mean daily air temperature for each date, as mean daily water and air temperatures are typically very similar in locations not strongly influenced by groundwater inflow (Poole and Berman 2001, Whitledge 2001). No attempt was made to account for diel water temperature fluctuations, as their effect on smallmouth bass growth is unknown. In addition to water temperatures, bioenergetics model simulations required information on diet composition, energy densities of smallmouth bass and their prey, food consumption rate,

\footnotetext{
${ }^{5}\langle$ http://www.ncdc.noaa.gov $\rangle$
}

and fish activity costs. Diet composition was set at 65\% crayfish and 35\% cyprinids (Rabeni 1992). Energy densities were set at $4184 \mathrm{~J} / \mathrm{g}$ for smallmouth bass (Whitledge et al. 2003), $3234 \mathrm{~J} / \mathrm{g}$ for crayfish (Rabeni 1992), and $3853 \mathrm{~J} / \mathrm{g}$ for cyprinids (Whitledge et al. 2003). Food consumption rate in all simulations was $0.035 \mathrm{~g}$ per gram of body mass per day to represent a long-term ad libitum feeding level (Whitledge et al. 2003). The activity multiplier (ACT) in the bioenergetics model was set at a value $20 \%$ above resting metabolism (1.2) based on mean daily swimming distance during summer for smallmouth bass in an Ozark stream (Todd and Rabeni 1989) and a relationship between distance swum and activity costs above resting metabolism for smallmouth bass reported by Cooke et al. (2001). All simulations were conducted for a fish with an initial mass of $227 \mathrm{~g}$; this represents an age 3-4 year-old fish at or approaching maturity (Pflieger 1975), at a size commonly found in small Ozark streams. Bioenergetics modeling simulations enabled assessment of the capacity of stream temperature regimes during summer to influence growth of older juvenile and adult smallmouth bass with all other growth-regulating factors held constant.

\section{Predicting the influence of riparian shading on summer thermal habitat for adult smallmouth bass at a watershed scale}

SNTEMP was used to estimate the degree to which riparian shading could increase the total linear extent of thermal habitat capable of supporting positive growth of adult smallmouth bass in northern Ozark and Ozark border streams during summer at a watershed scale. Four representative watersheds in the Meramec River basin that are known to contain smallmouth bass (Pflieger 1975) were chosen for this effort (Table 3). Streams within these watersheds generally flow in a northerly direction. These watersheds were selected because they are adjacent to one another and have similar lithologies, total linear stream distances, and watershed areas, but differ greatly in the number of springs present. Most springs within these watersheds are relatively small; only two springs with discharges $>0.042$ $\mathrm{m}^{3} / \mathrm{s}$ are present. Summer low-flow discharges were 
estimated for each stream segment using a model developed for Ozark streams by Ludwig and Tasker (1993). Stream segment lengths and spring locations were obtained from a GIS database developed by the Missouri Department of Natural Resources. Spring discharges were also obtained from the GIS database when available. Springs lacking discharge measurements were assigned a discharge of $0.00784 \mathrm{~m}^{3} / \mathrm{s}$, the median value of 626 springs in Missouri with discharges $<1.54 \mathrm{~m}^{3} / \mathrm{s}$. This approach assumed that springs lacking discharge data have relatively small discharges. Spring temperature was set at $13^{\circ} \mathrm{C}$. Stream width, slope, and travel time were set according to discharge, as in segment-scale simulations (Table 2). Meteorological parameters required by SNTEMP were identical to those used in simulations at the stream segment scale (Table 2). Total linear stream distance containing mean daily water temperatures $\leq 27^{\circ} \mathrm{C}$ (the upper thermal limit for positive growth of adult smallmouth bass as determined from bioenergetics model simulations) was predicted for each watershed with percentage of riparian shade set at both zero and at maximum levels given stream width and azimuth. Differences in total linear extent of thermal habitat capable of supporting adult smallmouth bass growth under fully shaded and unshaded conditions were calculated for each watershed. Within each watershed, the proportion of total stream distance that would be converted from sub-optimal thermal habitat (mean daily temperature $>27^{\circ} \mathrm{C}$ ) under unshaded conditions to thermal habitat capable of supporting adult smallmouth bass growth (mean daily temperature $\leq 27^{\circ} \mathrm{C}$ ) given maximal shading on all streams was also calculated.

\section{RESULTS}

\section{Effects of riparian shading on mean daily water temperature and daily temperature fluctuation in headwater streams}

Mean daily water temperatures measured in 18 headwater streams during 7-9 July 2000 ranged from $20.9^{\circ} \mathrm{C}$ to $28.5^{\circ} \mathrm{C}$ (Fig. 1a). Mean daily water temperatures in streams that were not spring-fed were never more than $1.6^{\circ} \mathrm{C}$ different from mean daily air temperature at Columbia Regional Airport during this period $\left(27.9^{\circ} \mathrm{C}\right)$. In spring-fed streams within $1 \mathrm{~km}$ of known spring locations, mean daily water temperatures ranged from $1.9^{\circ} \mathrm{C}$ to $7.0^{\circ} \mathrm{C}$ less than mean daily air temperature. For the combined set of spring-fed and nonspring-fed streams, there was no significant association between percentage of shade and mean daily water temperature $(P>0.1$; Fig. 1a). However, there was a significant linear relationship between percentage of shade and mean daily temperature fluctuation (daily maximum - daily minimum) measured in the combined set of 18 streams (daily temperature fluctuation $=-0.11$ $\times$ percentage shade $+8.51 ; r^{2}=0.79, P<0.001$; Fig. 1b). Mean daily temperature fluctuation ranged from $1.0^{\circ} \mathrm{C}$ in the most heavily-shaded stream to $9.2^{\circ} \mathrm{C}$ in an unshaded pasture stream. The predicted value for daily
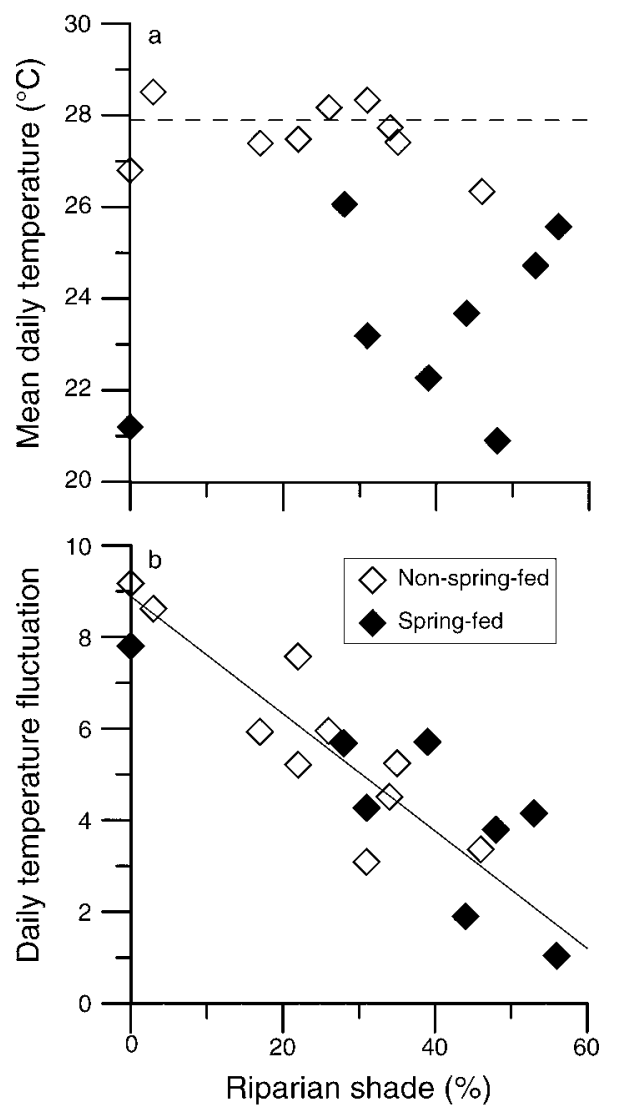

FIG. 1. (a) Mean daily water temperature and (b) mean daily temperature fluctuation (daily maximum - daily minimum) in 18 spring-fed and non-spring-fed headwater streams in the northern Ozarks and Ozark border region of Missouri, USA, during 7-9 July 2000, in relation to percentage of shade from riparian vegetation. The horizontal dashed line in panel (a) indicates mean daily air temperature. The solid line in panel (b) is a least-squares linear regression function fit to data (daily temperature fluctuation $=-0.11 \times$ percentage shade $+8.51 ; r^{2}=$ $0.79, P<0.001)$.

temperature fluctuation for a stream with zero shade was $8.5^{\circ} \mathrm{C}$, with upper and lower $95 \%$ confidence limits of $9.6^{\circ} \mathrm{C}$ and $7.4^{\circ} \mathrm{C}$, respectively. Spring-fed and nonspring-fed streams exhibited similar daily temperature fluctuation at equivalent levels of riparian shading.

\section{Maximum possible shade and stream size}

Maximum possible percentage of shade calculated by SSSHADE declined with increasing stream width for hypothetical representative north-south and east-west flowing streams in the northern Ozarks and Ozark border region (Fig. 2). For north-south flowing streams, maximum possible percentage of shade was predicted to decline in a near-linear fashion from $71 \%$ in streams with a width of $3 \mathrm{~m}$ to $52 \%$ in streams that were $20 \mathrm{~m}$ wide. Maximum possible percentage of shade for eastwest flowing streams was predicted to be less than that of north-south flowing streams of equivalent width for 


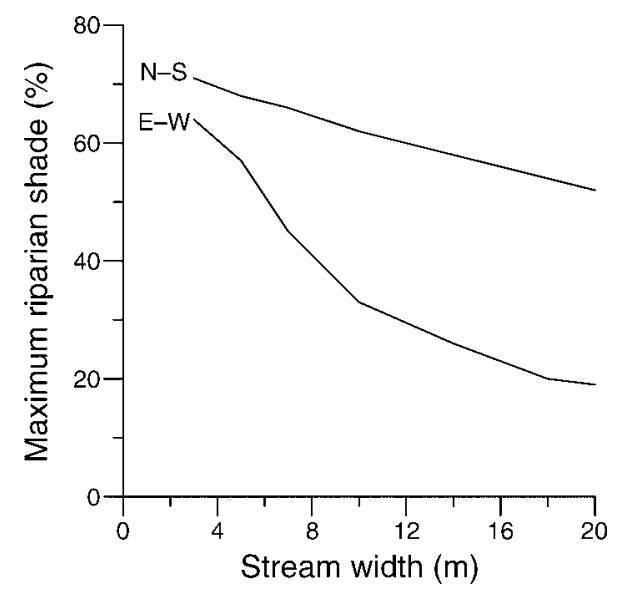

FIG. 2. Maximum possible percentage of riparian shade calculated using SSSHADE in relation to stream width for north-south $(\mathrm{N}-\mathrm{S})$ and east-west $(\mathrm{E}-\mathrm{W})$ flowing northern Ozark and Ozark Border streams ranging from $3 \mathrm{~m}$ to $20 \mathrm{~m}$ wide. Vegetation parameters used for calculating percentage of shade are shown in Table 1.

streams between 3 and $20 \mathrm{~m}$ wide, especially for streams $>6-8 \mathrm{~m}$ wide. For east-west flowing streams, maximum possible percentage of shade was predicted to be $64 \%$ for streams with a width of $3 \mathrm{~m}$, then declined rapidly to $57 \%, 45 \%$, and $33 \%$ at stream widths of 5,7 , and $10 \mathrm{~m}$, respectively.

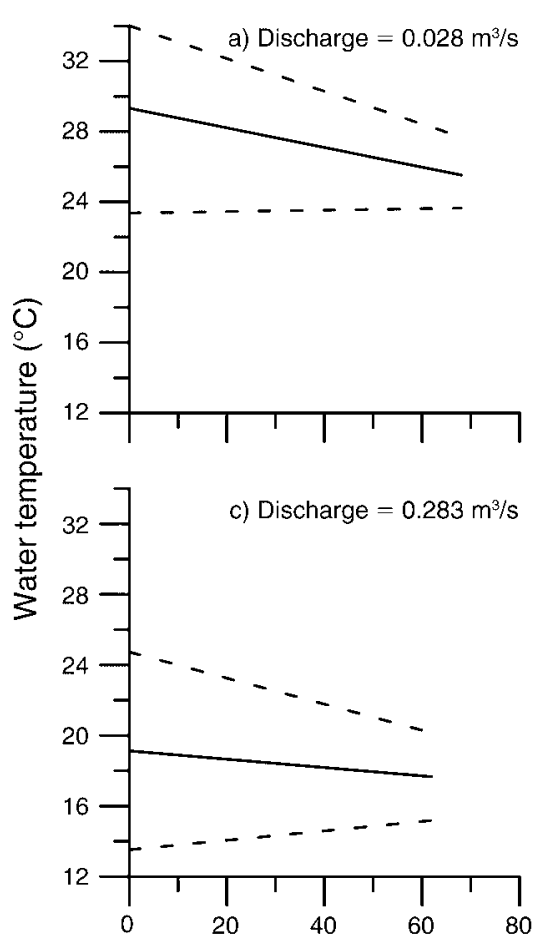

FIG. 3. Relationships between water temperature predicted by SSTEMP and percentage of riparian shade for 1-km reaches in spring-fed northern Ozark and Ozark Border streams (inflow temperature $13^{\circ} \mathrm{C}$ ) with four rates of discharge (a-d). Solid lines represent mean daily temperatures, and dashed lines represent daily maximum and minimum temperatures.
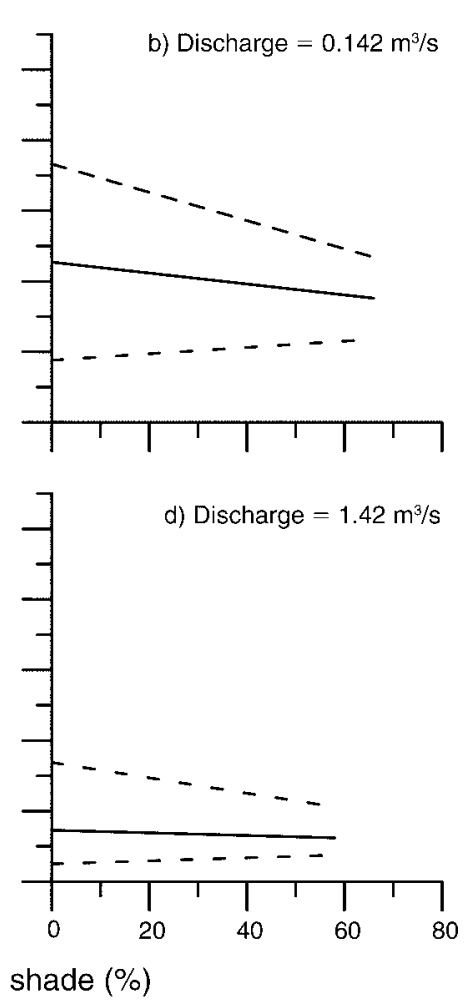

\section{Shade-water temperature relations for 1-km reaches}

In all simulations, mean daily stream temperature and daily temperature fluctuation declined with increasing levels of riparian shading (Figs. 3 and 4). Slopes of relations between mean daily water temperature and percentage of shade declined with increasing stream discharge, with slopes of these relations approaching zero at a discharge of $1.42 \mathrm{~m}^{3} / \mathrm{s}$. Daily maximum water temperatures were also predicted to be less affected by changes in riparian shading with increasing stream discharge. At a given value for percentage of shade, daily maximum temperatures and daily temperature fluctuation declined with increasing discharge, particularly at relatively low levels of riparian shading. Daily temperature fluctuation was predicted to range from as low as $1.98^{\circ} \mathrm{C}$ for a maximally shaded reach on a stream with a discharge of $1.42 \mathrm{~m}^{3} / \mathrm{s}$ to as high as $8.35^{\circ} \mathrm{C}$ for a reach with zero shade on a stream with a discharge of $0.028 \mathrm{~m}^{3} / \mathrm{s}$.

Mean daily water temperatures at the downstream end of hypothetical $1-\mathrm{km}$ reaches were predicted to be 2 $14^{\circ} \mathrm{C}$ lower for spring-fed streams compared to identically-sized streams not fed by groundwater (Figs. 3 and 4). However, slopes of relations between daily mean, maximum, and minimum stream temperatures and percentage of shade were similar for spring-fed and non-spring-fed streams of a given discharge. For all

Riparian shade (\%) 

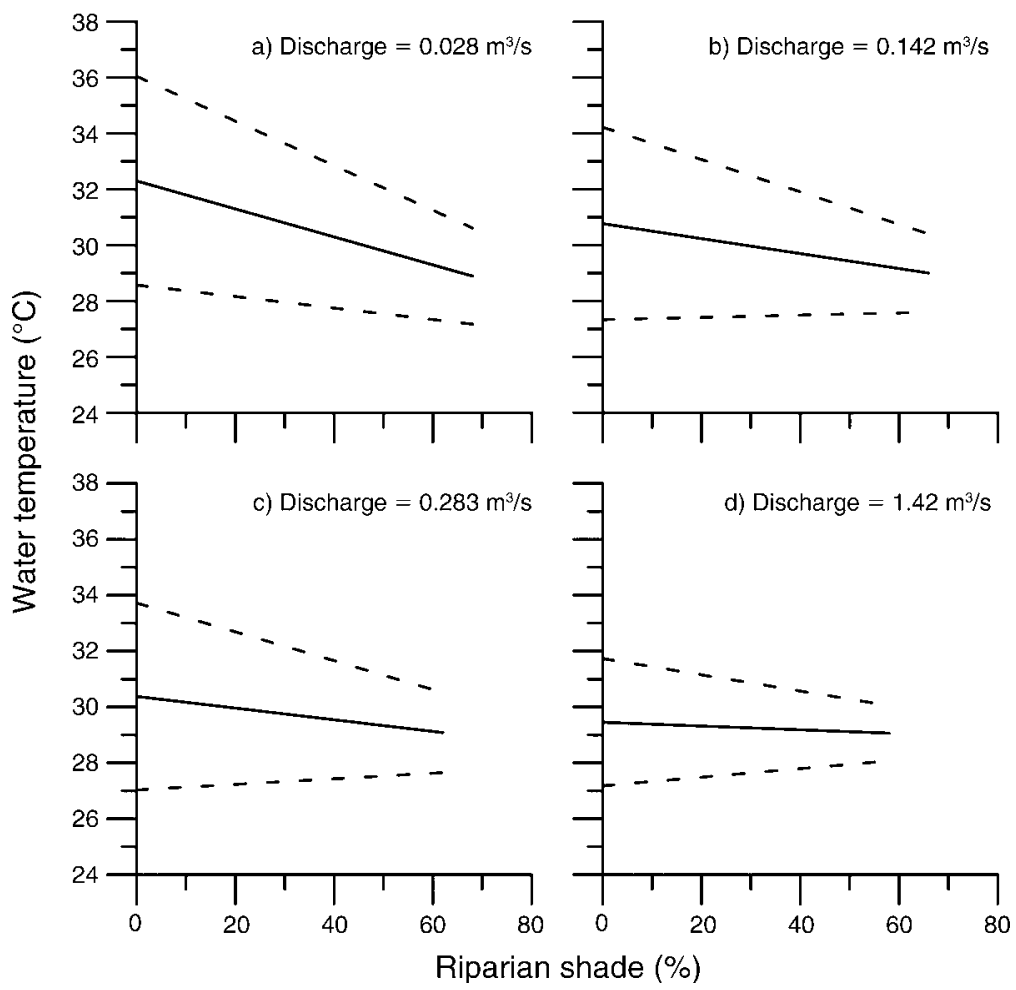

FIG. 4. Relationships between water temperature predicted by SSTEMP and percentage of riparian shade for 1-km reaches in non-spring-fed northern Ozark and Ozark Border streams (inflow temperature $29^{\circ} \mathrm{C}$ ) with four rates of discharge (a-d). Solid lines represent mean daily temperatures, and dashed lines represent daily maximum and minimum temperatures.

simulated reaches, stream temperatures were predicted to remain at or increase from inflow temperature after 1 $\mathrm{km}$. SSTEMP predicted that mean daily water temperatures would increase from $13^{\circ} \mathrm{C}$ to $\sim 27-30^{\circ} \mathrm{C}$ after 1 $\mathrm{km}$ for spring-fed streams with a discharge of $0.028 \mathrm{~m}^{3} / \mathrm{s}$ (Fig. 3a), but would only warm to $\sim 15^{\circ} \mathrm{C}$ for spring-fed streams with a discharge of $1.42 \mathrm{~m}^{3} / \mathrm{s}$ (Fig. 3d) over the same distance. For non-spring-fed streams, mean daily water temperatures were predicted to remain at inflow temperature used in simulations $\left(29^{\circ} \mathrm{C}\right)$ or to increase by up to $2.5^{\circ} \mathrm{C}$ after $1 \mathrm{~km}$, depending on discharge and percentage of shade (Fig. 4).

Increased levels of riparian shading were predicted to decrease rates of stream warming downstream from springs (Table 4) under meteorological conditions indicated in Table 2. Increasing riparian shading from zero to maximum predicted levels for a given stream size increased distances from a spring outflow required for streams to reach a daily mean temperature of $22^{\circ} \mathrm{C}$ by $12-60 \%(0.23-1.37 \mathrm{~km})$, depending on stream size and azimuth. For example, a stream originating at a spring with a discharge of $0.028 \mathrm{~m}^{3} / \mathrm{s}$ flowing north-south would reach $22^{\circ} \mathrm{C}$ in just $0.45 \mathrm{~km}$ with zero shade, but would not reach $22^{\circ} \mathrm{C}$ until it had traveled $0.72 \mathrm{~km}$ if maximally shaded. Potential for riparian shade to reduce longitudinal rates of stream warming was predicted to be greater for north-south than east-west flowing streams. Increasing riparian shading from zero to maximum predicted levels for a given stream size was forecasted to increase distances required for daily mean water temperature to warm to daily mean air temperature $\left(29.5^{\circ} \mathrm{C}\right)$ by $13-25 \%(0.25-1.21 \mathrm{~km})$ for east-west flowing streams and by $28-34 \%(0.32-2.55 \mathrm{~km})$ for north-south flowing streams.

TABLE 4. Distances $(\mathrm{km})$ from spring outlets with different discharge rates required for streams to warm from $13^{\circ} \mathrm{C}$ to mean daily temperatures of $22^{\circ} \mathrm{C}$ and $29.5^{\circ} \mathrm{C}$ for unshaded reaches and for maximally shaded streams flowing northsouth and east-west.

\begin{tabular}{|c|c|c|c|c|c|c|}
\hline \multicolumn{7}{|c|}{ Distance from spring outlet $(\mathrm{km})$} \\
\hline \multirow{2}{*}{$\begin{array}{l}\text { Discharge } \\
\left(\mathrm{m}^{3} / \mathrm{s}\right)\end{array}$} & \multicolumn{2}{|c|}{ Unshaded } & \multicolumn{2}{|c|}{ Maximum $\mathrm{N}-\mathrm{S}$} & \multicolumn{2}{|c|}{ Maximum E-W } \\
\hline & $22^{\circ} \mathrm{C}$ & $29.5^{\circ} \mathrm{C}$ & $22^{\circ} \mathrm{C}$ & $29.5^{\circ} \mathrm{C}$ & $22^{\circ} \mathrm{C}$ & $29.5^{\circ} \mathrm{C}$ \\
\hline 0.028 & 0.45 & 1.04 & 0.72 & 1.36 & 0.68 & 1.29 \\
\hline 0.142 & 1.11 & 2.10 & 1.49 & 2.81 & 1.34 & 2.54 \\
\hline 0.283 & 1.47 & 2.78 & 1.93 & 3.65 & 1.69 & 3.19 \\
\hline 1.420 & 4.81 & 9.09 & 6.16 & 11.64 & 5.42 & 10.30 \\
\hline
\end{tabular}

Notes: Northern Ozark and Ozark border streams were modeled under the meteorological conditions indicated in Table 2. Groundwater seepage was included for each hypothetical stream reach and varied with discharge as shown in Table 2. However, no tributaries or discharge from additional conduit springs were assumed to enter the stream within distances shown. 


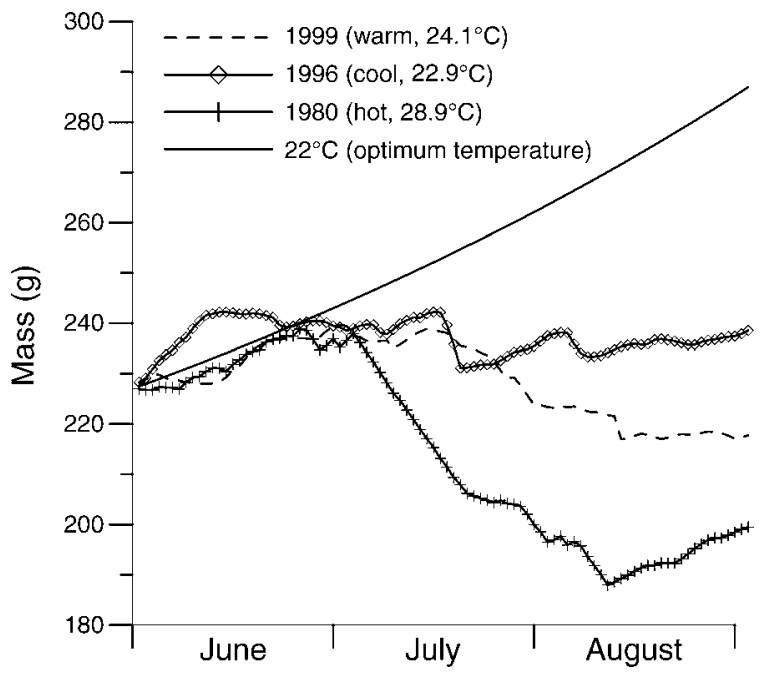

FIG. 5. Bioenergetics model growth predictions during June, July, and August for a 227-g smallmouth bass exposed to constant, optimum growth temperature $\left(22^{\circ} \mathrm{C}\right)$ and simulated stream thermal regimes during years when mean June-August air temperatures were $0.1^{\circ} \mathrm{C}$ below (1996), $1^{\circ} \mathrm{C}$ above (1999), and $6^{\circ} \mathrm{C}$ above (1980) the prior 30 -year averages for Columbia, Missouri, USA.

\section{Effects of summer temperature regimes on smallmouth bass growth}

Bioenergetics model simulations predicted that a smallmouth bass weighing $227 \mathrm{~g}$ on 1 June would grow to $287 \mathrm{~g}$ by 31 August under ad libitum feeding conditions and a constant optimum temperature of $22^{\circ} \mathrm{C}$ (Fig. 5). For the three temperature regimes designed to mimic day-to-day changes in mean water temperature in non-spring-fed streams, mean fish mass on 31 August was predicted to be $17-30 \%$ (49-88 g) lower compared to constant $22^{\circ} \mathrm{C}$ simulations when all growth-regulating factors except temperature were equivalent. Only during the summer in which mean monthly air temperatures were all at or below normal (1996) was a $227 \mathrm{~g}$ smallmouth bass predicted to gain mass (11 g) during June-August. An equivalent-sized smallmouth bass was predicted to lose about $10 \mathrm{~g}$ under a thermal regime in which mean June-August air temperature was $\sim 1^{\circ} \mathrm{C}$ above normal (1999) and was predicted to lose $\sim 27 \mathrm{~g}$ under a thermal regime in which mean air temperature over the same time period was $\sim 6^{\circ} \mathrm{C}$ above normal (1980). Mean daily air temperatures (and hence mean daily simulated water temperatures) exceeded $27^{\circ} \mathrm{C}$ for only a few days during late July 1996 , but exceeded $27^{\circ} \mathrm{C}$ for 16 consecutive days during late July 1999, and throughout most of July and early August 1980. Dates when temperatures exceeded $27^{\circ} \mathrm{C}$ coincided with periods when fish mass loss was predicted and were largely responsible for year-to-year differences in predicted fish masses for the three variable temperature scenarios at the end of August.

\section{Influence of riparian shading on summer thermal habitat for adult smallmouth bass at a watershed scale}

SNTEMP simulations indicated that increasing riparian shade from zero to maximal levels given stream size and azimuth would result in gains of $2660-11305 \mathrm{~m}$ in total linear extent of streams with mean daily temperatures $\leq 27^{\circ} \mathrm{C}$ within the four Meramec basin watersheds (Table 3). These gains in thermal habitat capable of supporting adult smallmouth bass growth represented $1.3 \%$ to $5.7 \%$ of total stream mileage within a given watershed. Greatest absolute and proportional increases in total stream distance with mean daily temperatures $\leq 27^{\circ} \mathrm{C}$ in response to increasing riparian shade occurred in the two watersheds with the highest spring densities.

\section{Discussion}

Results of our modeling simulations indicated that the buffering effect of riparian shade on water temperatures is not only important for growth and survival of coldwater stream fauna (Barton et al. 1985, Theurer et al. 1985, Hetrick et al. 1998, Blann et al. 2002), but can also enhance thermal habitat and growth potential for warmwater stream fishes. We have shown that riparian shading is capable of increasing longitudinal distances required for mean daily water temperature to warm from groundwater temperature to mean daily air temperature by $13-34 \%$ in spring-fed northern Ozark and Ozark border streams under the most extreme summer meteorological conditions that occur during an average year. Reduced stream warming rates will increase the amount of habitat potentially available to support positive growth of older juvenile and adult smallmouth bass. Rates of temperature increase for spring-fed streams predicted by SSTEMP revealed that increasing riparian shade from zero to maximum levels would increase longitudinal extent of mean daily water temperatures $<27^{\circ} \mathrm{C}$ (the temperature above which bioenergetics model simulations predicted scope-forgrowth for adult smallmouth bass would be negative) by $0.27-2.17 \mathrm{~km} \mathrm{(28-34 \% )}$ for north-south flowing streams with discharges ranging from $0.028-1.42 \mathrm{~m}^{3} / \mathrm{s}$ and by 0.21-1.03 km (13-24\%) for east-west flowing streams of identical sizes. Reductions in stream warming rates resulting from increased riparian shading would also likely benefit endemic Ozark crayfishes that have optimum growth temperatures identical to that of adult smallmouth bass $\left(22^{\circ} \mathrm{C}\right.$; Whitledge and Rabeni 2002). Conditions that promote positive crayfish growth would be expected to enhance crayfish fecundity (Corey 1987, Muck et al. 2002) and therefore could ultimately result in larger crayfish population sizes. Thus, cooler temperatures provided by riparian shading downstream from springs would increase smallmouth bass growth potential directly and indirectly through effects on their primary prey.

SSTEMP simulations and empirical temperature data also indicated that riparian shading substantially limits daily temperature fluctuation in warmwater Ozark 
streams, as it does along coldwater streams (e.g., Brown and Krygier 1970, Burton and Likens 1973, Barton et al. 1985, Hetrick et al. 1998). Ozark and Ozark border streams with near-maximum levels of riparian shading were predicted to experience daily temperature fluctuations $<2^{\circ} \mathrm{C}$, while daily temperature fluctuations may reach $8-9^{\circ} \mathrm{C}$ in unshaded or lightly-shaded streams. Differences between daily maximum and daily minimum temperatures predicted by the SSTEMP model for unshaded streams with a discharge of $0.028 \mathrm{~m}^{3} / \mathrm{s}$ $\left(7.53-8.96^{\circ} \mathrm{C}\right)$ were similar to daily temperature fluctuation determined for an unshaded stream of similar size using the regression equation fit to empirical water temperature data $\left(8.5^{\circ} \mathrm{C}, 95 \%\right.$ confidence interval 7.4 $9.6^{\circ} \mathrm{C}$ ); these results support the validity of SSTEMP's predictions for warmwater as well as coldwater streams. Fish community structure in small, permanently-flowing Ozark streams has been demonstrated to be strongly related to maximum summer water temperatures (Rabeni et al. 1997), suggesting that moderation of daily stream temperature fluctuation by riparian shading is important for restoration or maintenance of native coolwater fish communities. Effects of diel water temperature fluctuations on fish growth are uncertain, although shading may prevent daily maximum temperatures from substantially exceeding thermal growth optima for coolwater species in some locations. Jobling (1997) suggested that fluctuating temperatures may reduce growth when mean temperature is above optimum, have little effect on growth at near-optimum mean temperatures, and increase growth when mean temperature is below optimum. If so, then streams that exhibit temperatures fluctuating around a mean daily temperature substantially $>22^{\circ} \mathrm{C}$ could be even less conducive to adult smallmouth bass growth than predicted from constant daily temperatures used in our bioenergetics model simulations. Effects of fluctuating water temperatures on fish growth and food consumption represent an important area for future research to improve understanding of linkages between riparian conditions and bioenergetics of lotic fishes.

Although riparian shading substantially reduces stream warming rates downstream from spring outlets, SSTEMP simulations and empirical data indicated that riparian shading alone is insufficient to yield mean daily water temperatures $>2^{\circ} \mathrm{C}$ below mean daily air temperature during summer (Fig. 1a). Such temperatures will only occur downstream from substantial groundwater inflows where streams have not yet achieved thermal equilibrium. Mean daily water temperatures in streams fed exclusively by surface runoff were predicted to remain within $2^{\circ} \mathrm{C}$ of mean daily air temperature during summer low-flow conditions irrespective of riparian shading. Thus, groundwater inputs from springs are required for adult smallmouth bass in warmwater streams to experience mean daily water temperatures that are optimal for growth $\left(22^{\circ} \mathrm{C}\right)$ when mean daily air temperatures exceed $24-25^{\circ} \mathrm{C}$. Groundwater plays an important role in preventing summer water temperatures from exceeding critical thermal maxima for coldwater stream fishes (Power et al. 1999). Many Ozark stream fishes use large spring branches as winter refugia from colder temperatures in adjoining streams (Peterson and Rabeni 1996). Whether these spring branches are also used by older juvenile and adult smallmouth bass to avoid suboptimal water temperatures during summer is unknown.

Bioenergetics model simulations revealed that adult smallmouth bass in locations not influenced by groundwater inputs would be subject to periods of mass loss when stream temperatures exceeded $27^{\circ} \mathrm{C}$, even if food was unlimited, and would likely exhibit greater interannual variation in growth during summer as a consequence of year-to-year differences in weather patterns. Potential for mass loss was particularly severe under the 1980 thermal regime (mean June-August air temperature $5.9^{\circ} \mathrm{C}$ above normal), suggesting that predicted temperature changes under a doubling of atmospheric $\mathrm{CO}_{2}$ (Eaton and Scheller 1996) could greatly diminish smallmouth bass growth rates in streams lacking thermal refugia associated with groundwater inputs. For protection of positive growth potential for adult smallmouth bass (Armour 1990), a temperature of $27^{\circ} \mathrm{C}$ corresponds to the maximum weekly average temperature that should not be exceeded, given an optimum growth temperature of $22^{\circ} \mathrm{C}$ (Whitledge et al. 2002) and an upper ultimate incipient lethal temperature of $37^{\circ} \mathrm{C}$ (Wrenn 1980 ); $27^{\circ} \mathrm{C}$ is $2^{\circ} \mathrm{C}$ lower than the maximum safe temperature limit recommended for growth of juvenile smallmouth bass by Horning and Pearson (1973). Reduced growth rates during extended periods of temperatures $>27^{\circ} \mathrm{C}$ could lead to diminished annual growth, fish condition, and ultimately, fecundity (Bagenal 1967), and could thus negatively influence population size. The $27^{\circ} \mathrm{C}$ threshold for distinguishing streams that can and cannot support positive growth of adult smallmouth bass is conservative, as it is based on fish feeding on an unlimited prey supply; if prey supply were limited, the temperature threshold would be lower. Adverse effects of temperatures $>27^{\circ} \mathrm{C}$ would also likely be significant for endemic Ozark crayfishes that are, energetically, the most important prey for adult smallmouth bass (Rabeni 1992) and also exhibit declining growth scope at temperatures $>22^{\circ} \mathrm{C}$ (Whitledge and Rabeni 2002).

Optimum temperature for growth of age-0 smallmouth bass $\left(29^{\circ} \mathrm{C}\right)$ is substantially higher than that of older conspecifics (Shuter and Post 1990), so water temperatures from $27-29^{\circ} \mathrm{C}$ are anticipated to negatively affect growth of older juvenile and adult smallmouth bass but not young-of-the-year. A bioenergetics model for age-0 smallmouth bass (Hewett and Johnson 1992) indicates that their growth scope increases with increasing temperature up to $29^{\circ} \mathrm{C}$, then declines rapidly at higher temperatures. Mean daily air temperatures exceeding the optimum growth temperature for age-0 
smallmouth bass occur on an average of only six days per year in Columbia, Missouri and do not exceed the maximum weekly average temperature recommended for adequate growth of age- 0 fish $\left(32-33^{\circ} \mathrm{C}\right.$; Wrenn 1980) during most years (National Climate Data Center, unpublished data). Thus, groundwater inflow is usually not required to prevent mean daily water temperatures from exceeding optimum growth temperature for age- 0 smallmouth bass during summer in Ozark and Ozark border streams. Growth potential for age- 0 fish is expected to be greatest in locations not influenced by groundwater when mean daily air temperatures are higher than groundwater temperature $\left(13^{\circ} \mathrm{C}\right)$ but do not result in water temperatures exceeding $29^{\circ} \mathrm{C}$. Differences in characteristics of streams that possess optimal thermal habitat for age- 0 and adult smallmouth bass during summer suggest that watersheds that will be best for smallmouth bass populations during summer will possess maximally-shaded spring-fed streams (for promotion of adult smallmouth bass growth, condition, and fecundity) in close proximity to areas not strongly influenced by groundwater (for promotion of age-0 smallmouth bass growth). Summer growth is important for age- 0 smallmouth bass because overwinter survival is positively related to fish size at the end of their first growing season (Shuter et al. 1980).

Riparian restoration efforts intended to increase thermal habitat capable of supporting adult smallmouth bass growth during summer in spring-fed warmwater streams such as those in the Missouri Ozarks should take into consideration the effects of stream azimuth on riparian vegetation shade yield. SSTEMP simulations indicated that stream azimuth is important in affecting water temperature in Ozark streams with discharges $<0.28 \mathrm{~m}^{3} / \mathrm{s}$ and widths of $6-12 \mathrm{~m}$, because water temperatures in streams of this size are sensitive to changes in shading and percentage of shade is substantially different between north-south and east-west flowing streams in this size range. For streams $<5 \mathrm{~m}$ wide, azimuth has less influence on maximum possible shade because the riparian canopy tends to more completely overhang and enclose such small stream channels and blocks similar amounts of solar radiation for north-south and east-west flowing streams. Thus, efforts to restore riparian vegetation will have their greatest potential for substantially increasing riparian shading and affecting temperatures in small streams (those $<5 \mathrm{~m}$ wide) or in north-south flowing stream reaches between 6 and $12 \mathrm{~m}$ wide. Estimates of maximum possible percentage of shade presented herein do not account for additional shade that may result from topographic features. Many Ozark streams flow through rolling hills and near steep bluffs along a portion of their courses, and such features will increase maximum possible percentage of shade beyond levels predicted to result from mature riparian vegetation alone.
Temperature model simulations for four representative watersheds indicated that restoring riparian shading to maximum levels throughout a watershed would result in limited gains in total linear distance of streams with mean daily temperatures capable of supporting adult smallmouth bass growth under summer low-flow conditions when mean daily air temperatures are at or near their average annual maximum. Predicted increase in habitat with mean daily temperatures $\leq 27^{\circ} \mathrm{C}$ in response to restoring riparian shade from zero to maximum levels represented only $\sim 5 \%$ of total stream mileage even in watersheds with spring densities approaching one spring per square kilometer. Limited potential for increasing thermal habitat with the capacity to support summer growth of adult smallmouth bass through watershedscale riparian restoration is a consequence of the fact that many Ozark springs have relatively low discharges and their influence on stream temperatures extends only a short distance downstream and that springs tend to occur in clusters and are absent from many stream segments. Although riparian restoration along streams not influenced by groundwater may provide some benefits to native fishes through moderation of daily water temperature fluctuation (Rabeni et al. 1997), such efforts will not increase the temporal or spatial extent of mean daily water temperatures that are more optimal for adult smallmouth bass than largemouth bass. Therefore, restoration of riparian vegetation along Ozark and Ozark border streams with objectives of increasing thermal habitat capable of supporting summer growth of adult smallmouth bass and reducing stream mileage in which largemouth bass have a bioenergetic advantage (Zweifel et al. 1999, Whitledge et al. 2002) should be focused on stream reaches immediately downstream from springs rather than at a watershed scale. However, watersheds with relatively high spring densities are inherently less subject to geographic isolation of suitable thermal habitats. Focusing riparian management in groundwater-influenced reaches will increase fiscal and ecological efficiency of efforts to reverse declines in smallmouth bass abundance in Ozark and Ozark border streams. The greatest potential for gains in optimal thermal habitat for adult smallmouth bass growth will occur immediately downstream from relatively large springs or clusters of smaller springs. Identification and protection of groundwater recharge areas for springs should also be a priority.

It is important to emphasize that our recommendations for riparian vegetation management are related solely to objectives concerning summer water temperatures in warmwater streams, such as those in the Ozark and Ozark border regions. Riparian vegetation performs many other functions for streams, including moderating variation in stream discharge (Hornbeck et al. 1970), reducing siltation and sediment influx (Rabeni and Smale 1995), reducing nutrient and contaminant inputs (Peterjohn and Correll 1984), providing a source of 
organic matter, stabilizing stream banks, and providing woody debris habitat (Rabeni 1993). Amounts of riparian vegetation adequate for producing sufficient shade to achieve some summer water temperature-based objective may or may not be capable of performing other functions that may be equally or more important to maintenance or restoration of stream habitat for particular species or assemblages. Future research should seek to integrate the multiple roles of riparian vegetation into recommended quantities of riparian vegetation required to maintain or restore suitable habitat for lotic biota.

\section{ACKNOWLEDGMENTS}

This is a contribution of the Missouri Cooperative Fish and Wildlife Research Unit (Biological Resources Division of the United States Geological Survey, Missouri Department of Conservation, University of Missouri at Columbia, and Wildlife Management Institute Cooperating). Funding for this research was provided by the Missouri Department of Conservation with the aid of Bob DiStefano. We thank Mike Whitacre for assistance in the field.

\section{Literature Cited}

Allan, J. D. 1995. Stream ecology: structure and function of running waters. Chapman and Hall, New York, New York, USA.

Armour, C. L. 1990. Guidance for evaluating and recommending temperature regimes to protect fish. U.S. Fish and Wildlife Service Biological Report 90(22). Washington, D.C., USA.

Bagenal, T. B. 1967. A short review of fish fecundity. Pages 89 111 in S. B. Gerking, editor. The biological basis of freshwater fish production. Wiley, New York, New York, USA.

Bartholow, J. M. 1989. Stream temperature investigations: field and analytic methods. Instream flow information paper number 13. U.S. Fish and Wildlife Service Biological Report 89(17). Washington, D.C., USA.

Bartholow, J. M. 1991. A modeling assessment of the thermal regime for an urban sport fishery. Environmental Management 15:833-845.

Bartholow, J. M. 2000. Estimating cumulative effects of clearcutting on stream temperatures. Rivers 7:284-297.

Bartholow, J. M., J. L. Laake, C. B. Stalnaker, and S. C. Williamson. 1993. A salmonid population model with emphasis on habitat limitations. Rivers 4:265-279.

Barton, D. R., W. D. Taylor, and R. M. Biette. 1985. Dimensions of riparian buffer strips required to maintain trout habitat in southern Ontario streams. North American Journal of Fisheries Management 5:364-378.

Bauman, A. C. 1945. Report of a fisheries survey of the streams of Missouri with recommendations for their management. Missouri Conservation Commission, Division of Fish, Game, and Forests, Missouri Wildlife Resources Project 12, Jefferson City, Missouri, USA.

Beschta, R. L., and R. L. Taylor. 1988. Stream temperature increases and land use in a forested Oregon watershed. Water Resources Bulletin 24:19-25.

Blann, K., J. F. Nerbonne, and B. Vondracek. 2002. Relationship of riparian buffer type to water temperature in the driftless area ecoregion of Minnesota. North American Journal of Fisheries Management 22:441-451.

Brown, G. W., and J. T. Krygier. 1970. Effects of clearcutting on stream temperature. Water Resources Research 6:11331139.

Burton, T. M., and G. E. Likens. 1973. The effect of stripcutting on stream temperatures in the Hubbard Brook
Experimental Forest, New Hampshire. BioScience 23:433435.

Collier, J. E. 1955. Geographic regions of Missouri. Annals of the Association of American Geographers 45:368-392.

Cooke, S. J., C. M. Bunt, J. F. Schreer, and D. H. Wahl. 2001. Comparison of several techniques for mobility and activity estimates of smallmouth bass in lentic environments. Journal of Fish Biology 58:573-587.

Corey, S. 1987. Comparative fecundity of four species of crayfish in southwestern Ontario, Canada (Decapoda, Astacidea). Crustaceana 52:276-280.

Coutant, C. C. 1976. Thermal effects on fish ecology. Pages 891-896 in Encyclopedia of environmental engineering. Volume 2. W \& G Baird, Northern Ireland, UK.

Coutant, C. C. 1999. Perspectives on temperature in the Pacific Northwest's fresh waters. Oak Ridge National Laboratory Environmental Sciences Division Publication 4849 (ONRL/ TM-1999/44). Oak Ridge, Tennessee, USA.

Eaton, J. G., and R. M. Scheller. 1996. Effects of climate warming on fish thermal habitat in streams of the United States. Limnology and Oceanography 41:1109-1115.

Fajen, O. F. 1981. Recent changes in the distribution and relative abundance of smallmouth bass and spotted bass in Missouri streams. Pages 3-4 in D. C. Jackson, editor. Proceedings of the First International Smallmouth Bass Symposium. Mississippi Agricultural and Forest Experiment Station, Mississippi State University, Starkville, Missippi, USA.

Fry, F. E. J. 1971. The effect of environmental factors on the physiology of fish. Pages $1-98$ in W. S. Hoar, and D. J. Randall, editors. Fish physiology. Volume VI. Academic Press, New York, New York, USA.

Hetrick, N. J., M. A. Brusven, W. R. Meehan, and T. C. Bjornn. 1998. Changes in solar input, water temperature, periphyton accumulation, and allochthonous input and storage after canopy removal along two small salmon streams in southeast Alaska. Transactions of the American Fisheries Society 127:859-875.

Hewett, S. W., and B. L. Johnson. 1992. Fish bioenergetics model 2. Technical Report WIS-SG-92-250, University of Wisconsin, Sea Grant Institute, Madison, Wisconsin, USA.

Hewlett, J. D., and J. C. Fortson. 1982. Stream temperature under an inadequate buffer strip in the southeast Piedmont. Water Resources Bulletin 18:983-988.

Holmes, R. M. 2000. The importance of ground water to stream ecosystem function. Pages 137-148 in J. B. Jones, and P. J. Mulholland, editors. Streams and ground waters. Academic Press, San Diego, California, USA.

Hornbeck, J. W., R. S. Pierce, and C. A. Federer. 1970. Streamflow changes after forest clearing in New England. Water Resources Research 6:1124-1132.

Horning, W. B., II, and R. E. Pearson. 1973. Growth temperature requirements and lower lethal temperatures for juvenile smallmouth bass (Micropterus dolomieui). Journal of the Fisheries Research Board of Canada 30:1226-1230.

Jobling, M. 1997. Temperature and growth: modulation of growth rate via temperature change. Pages 225-253 in C. M. Wood, and D. G. McDonald, editors. Global warming: implications for freshwater and marine fish. Cambridge University Press, Cambridge, UK.

Ludwig, A. H., and G. D. Tasker. 1993. Regionalization of low flow characteristics of Arkansas streams: U.S. Geological Survey Water-Resources Investigations Report 93-4013. Little Rock, Arkansas, USA.

Matthews, W. J. 1987. Physicochemical tolerance and selectivity of stream fishes as related to their geographic ranges and local distributions. Pages 111-120 in W. J. Matthews, and D. C. Heins, editors. Community and evolutionary ecology of North American stream fishes. University of Oklahoma Press, Norman, Oklahoma, USA. 
MDC (Missouri Department of Conservation). 1991. Missouri forests: their history, values, and management. Missouri Department of Conservation, Jefferson City, Missouri, USA.

Muck, J. A., C. F. Rabeni, and R. J. DiStefano. 2002. Reproductive biology of the crayfish Orconectes luteus (Creaser) in a Missouri stream. American Midland Naturalist 147:338-351.

Newbold, J. D., D. C. Erman, and K. B. Roby. 1980. Effects of logging on macroinvertebrates in streams with and without buffer strips. Canadian Journal of Fisheries and Aquatic Sciences 37:1076-1085.

Newcomb, T. J. 1998. Productive capacity of the Betsie River watershed for steelhead smolts. Dissertation. Michigan State University, East Lansing, Michigan, USA.

Peterjohn, W. T., and D. C. Correll. 1984. Nutrient dynamics in an agricultural watershed: observations on the role of a riparian forest. Ecology 65:1466-1475.

Peterson, J. T., and C. F. Rabeni. 1996. Natural thermal refugia for temperate warmwater stream fishes. North American Journal of Fisheries Management 16:738-746.

Pflieger, W. L. 1975. The fishes of Missouri. Missouri Department of Conservation, Jefferson City, Missouri, USA.

Poole, G. C., and C. H. Berman. 2001. An ecological perspective on in-stream temperature: natural heat dynamics and mechanisms of human-caused thermal degradation. Environmental Management 27:787-802.

Power, G., R. S. Brown, and J. G. Imhof. 1999. Groundwater and fish: insights from northern North America. Hydrological Processes 13:401-422.

Rabeni, C. F. 1992. Trophic linkage between stream centrarchids and their crayfish prey. Canadian Journal of Fisheries and Aquatic Sciences 49:1714-1721.

Rabeni, C. F. 1993. Warmwater streams. Pages 427-443 in C. C. Kohler, and W. A. Hubert, editors. Inland fisheries management in North America. American Fisheries Society, Bethesda, Maryland, USA.

Rabeni, C. F., and M. A. Smale. 1995. Effects of siltation on stream fishes and the potential mitigating role of the buffering riparian zone. Hydrobiologia 303:211- 219.

Rabeni, C. F., M. A. Smale, and E. B. Nelson. 1997. Water quality and riparian conditions in the upper Niangua River basin, 1991-1995; effects upon fish and invertebrate communities. Completion report, Missouri Department of Natural Resources, Division of Environmental Quality, Jefferson City, Missouri, USA.

Rutherford, J. C., N. A. Marsh, P. M. Davies, and S. E. Bunn. 2004. Effects of patchy shade on stream water temperature: how quickly do small streams heat and cool? Marine and Freshwater Research 55:737-748.

Shuter, B. J., J. A. MacLean, F. E. J. Fry, and H. A. Regier. 1980. Stochastic simulation of temperature effects on firstyear survival of smallmouth bass. Transactions of the American Fisheries Society 119:314-336.

Shuter, B. J., and J. R. Post. 1990. Climate, population viability, and the zoogeography of temperate fishes. Transactions of the American Fisheries Society 119:314-336.

Smale, M. A., and C. F. Rabeni. 1991. The effects of special area land treatment (SALT) agricultural management practices on the biological health of headwater streams. Final report to Missouri Department of Natural Resources, Water Quality Division, Jefferson City, Missouri, USA.

Smale, M. A., and C. F. Rabeni. 1995. Hypoxia and hyperthermia tolerances of headwater stream fishes. Transactions of the American Fisheries Society 124:698-710.

Sowa, S. P., and C. F. Rabeni. 1995. Regional evaluation of the relation of habitat to distribution and abundance of smallmouth bass and largemouth bass in Missouri streams. Transactions of the American Fisheries Society 124:240-251.

Sullivan, K., and T. N. Adams. 1989. The physics of stream heating: 2) an analysis of temperature patterns in stream environments based on physical principles and field data. Weyerhaeuser Corporation Technical Report, Project Number 044- 5002/89/2. Tacoma, Washington, USA.

Sweeney, B. W. 1995. Effects of streamside vegetation on macroinvertebrate communities of White Clay Creek in eastern North America. Journal of the North American Benthological Society 14:291-335.

Theurer, F. D., I. Lines, and T. Nelson. 1985. Interaction between riparian vegetation, water temperature, and salmonid habitat in the Tucannon River. Water Resources Bulletin 21:53-64.

Thom, R. H., and J. H. Wilson. 1980. The natural divisions of Missouri. Transactions of the Missouri Academy of Science 14:9-23.

Todd, B. L., and C. F. Rabeni. 1989. Movement and habitat use by stream-dwelling smallmouth bass. Transactions of the American Fisheries Society 118:229-242.

Tryon, C. P. 1974. Surface water hydrology of the Little Piney Creek watershed. Open file report, Clark National Forest, Rolla, Missouri, USA.

Whitledge, G. W. 2001. Quantifying linkages between riparian shading, water temperature, and energetics of smallmouth bass and crayfishes in Ozark streams. Dissertation. University of Missouri, Columbia, Missouri, USA.

Whitledge, G. W., R. S. Hayward, and C. F. Rabeni. 2002. Effects of temperature on specific daily metabolic demand and growth scope of sub-adult and adult smallmouth bass. Journal of Freshwater Ecology 17:353-361.

Whitledge, G. W., R. S. Hayward, R. D. Zweifel, and C. F. Rabeni. 2003. Development and laboratory evaluation of a bioenergetics model for sub-adult and adult smallmouth bass. Transactions of the American Fisheries Society 132: 316-325.

Whitledge, G. W., and C. F. Rabeni. 2002. Maximum daily consumption and respiration rates at four temperatures for five species of crayfish from Missouri, U.S.A. (Decapoda, Orconectes spp.). Crustaceana 75:1119-1132.

Wrenn, W. B. 1980. Effects of elevated temperature on growth and survival of smallmouth bass. Transactions of the American Fisheries Society 109:617-625.

Zweifel, R. D., R. S. Hayward, and C. F. Rabeni. 1999. Bioenergetics insight into black bass distribution shifts in Ozark border region streams. North American Journal of Fisheries Management 19:192-197. 